\title{
LEGAL ASPECTS OF JUSTICE IN CRIMINAL LAW ENFORCEMENT
}

\author{
Carolina da Cruz \\ Oriental Timor Lorosae University \\ linacruz4492@gmail.com
}

\begin{abstract}
Criminal Law enforcement is an effort to realize legal ideas and concepts oriented to legal certainty as a noble ideal that must be applied by the state. The implementation of justice in criminal law enforcement in Indonesia can be said to be far from the goals to be realized by the rule of law. Enforcement of law and justice in the context of a fair legal process is a guarantee of the rule of law based on the constitution that must be able to realize and be felt by the people seeking justice as a reality. The law that is implemented and enforced must be a law that contains the values of justice, therefore, the true nature of law enforcement lies in the activity of harmonizing the relationships of values that are interpreted in the rules that are stable and manifest and act as a series of translation of the stage value the end, to create, preserve, and maintain the peace of association of life. In essence, the establishment of law and justice is a form of human welfare physically and mentally, socially and morally.
\end{abstract}

Keywords: Criminal law emforcement; Juctice; Legal Aspect.

\section{A. INTRODUCTION}

The main issue or legal issue that is often debated is the fair legal process as the ideals of the law (rechtsidee) in a civilized country, which is included in the sentence (fair legal process). Opponent of this process is "arbitrary process" (arbitrary process). "Arbitrary processes" which are often carried out solely based on the use of discretionary power by law enforcers by deviating and forcing a will on the grounds that it is in accordance with the legal process and the Standard Operating Procedure.

The legal instruments were made aimed at creating justice, especially for the common people. For this reason, law enforcers such as prosecutors and judges must refer to the goal of realizing justice in the enforcement of a fair legal process. ${ }^{1}$

The judicial power is an independent power to administer justice in order to enforce law and justice. That forcing a will on the pretext of justice is unjustifiable, because the justice to be forced is certainly very subjective. Justice according to individuals or groups of people is always subjective in nature, which does not necessarily reflect true justice. ${ }^{2}$ And that justice resulting

1 Abdul Latif, 2014, Hukum Administrasi Dalam Praktik Tindak Pidana Korupsi, Cetakan Kesatu, Kencana Prenada Media Group, Jakarta, P.156.

2 Harifin A. Tumpa, 2011, Transparansi Merupakan Pintu Keadilan Dan Kebenaran, 
from a process will depend on how the judge interprets and applies existing law, both formal and material law.

Law enforcement is essentially a process to realize legal goals, legal ideas become reality. Law enforcement is a process of activities or activities one of which is carried out by law enforcement. To produce good law enforcement, the process of each stage in law enforcement must be done properly and correctly. Criminal law enforcement is an effort to enforce the norms of criminal law along with all values that are behind the norm, which is limited by the "area of no enforcement" through criminal procedural law or other special provisions, to maintain a balance between state interests, interests general and individual interests. So that the legal development can be as expected so far.

In realizing the goals of the State, it is not easy like turning the palm of the hand, many problems and problems that must be faced by the State of Indonesia, especially legal issues. Consequences The State of Indonesia is a state of law that is that every attitude, policy and behavior of the state and population must be based on law. ${ }^{3}$

The practice in the law enforcement environment is the

Pidato Pemberian Penghargaan Doktor Honoris Causa Dari Universitas Hasanuddin Makassar, P. 19-21.

3 Achmad Sulchan, Rekonstruksi Penegakan Hukum Terhadap Perkara Pidana Pemilihan Umum Berbasis Nilai Keadilan, Jurnal Pembaharuan Hukum Volume I No. 3 September - Desember 2014, P. $350-359$ closure or lack of transparency in every process. At each stage of the process, law enforcement officials deliver the results, so that justice seekers can find out whether the process is in accordance with the Standard Operating Procedures that must be delivered transparently by the agency. However, poor law enforcement cannot also be relied entirely on law enforcement, because it cannot be separated from the role of the parties in the case.

\section{B. DISCUSSION}

\section{Implementation of Justice in Criminal Law Enforcement}

The main problem in the implementation of law and justice is human, so the main human problem in the context of a fair legal process is justice. Hans Kelsen who is a pioneer of pure law teaches that the notion of law must be distinguished from the notion of justice. The answer to the question about the conduct of the law so that its principles must be implemented and obeyed, very much depends on the established relationship between law and justice. The relationship is basically in accordance with Gustav Radbruch's view that the law could be unjust, but the law is only law because it wants to be fair. However, the relationship between law and justice as formulated by Radbruch has not yet explained many issues concerning the nature of justice itself and thus also the question 
of whether the law is conducive to justice. ${ }^{4}$

It is no exaggeration to say that Radbruch's formulation is just the beginning of the problem of seeking clarity about the nature of justice, because by stating that "law is only law because it wants to be fair" does not yet explain why law is necessarily a correlation of justice. Even though there is a distinction between law and justice, as well as efforts to put the two in a functional relationship, the justice to be achieved through that law is essential for any country including the Indonesian state law. Therefore, it is no exaggeration to say that a country that does not reflect justice does not need to call itself a state of law.

In Daniel S. Lev's dissertation, it has also been elaborated on the contradiction between government equipment, especially regarding the Republic of Indonesia's attorney's office. The polemic regarding his position has also not been resolved to date, The parlement wants an independent and independent prosecutor's office, while some prosecutors themselves want to be under the authority of a judicial institution. ${ }^{5}$

The rule of law is a country that optimally enforces

4 Abdul Latif, Hukum Administrasi.., op.cit., P.157 dan 158.

5 Daniel S. Lev, Hukum dan Politik di Indonesia, Kesinambungan dan Perubahan., LP3ES, Jakarta, P. 36. the law, upholds human rights and guarantees citizens at the same time their position in the law and the government is obliged to uphold the law and government with no exception. Then law enforcement becomes one of the parameters in the success of the rule of law. ${ }^{6}$

The general problem that is immediately faced is how does the certainty of the law present itself before the public? Although the legal certainty must have formal authority and material in order to feel its presence, so that legal certainty also has a performance that can be observed by the public, which increasingly has an increasing a feeling is quite sensitive to injustice. This means that legal certainty is assessed through the impact of justice that it produce. Formal performance is generated by consistency in the application of methods and procedures that are relatively similar to a behavior that deviates from legal norms, or as stated by Rawls that: "Formal justice is adherence to principle, or as some have said, obedience to system ".

Rawls gives such a high value to the systemic

6 Sri Endah Wahyuningsih, Rismanto, Kebijakan Penegakan Hukum Pidana Terhadap Penanggulangan Money Laundering Dalam Rangka Pembaharuan Hukum Pidana Di Indonesia, Jurnal Pembaharuan Hukum, Volume II No. 1 Januari - April 2015, P.46-56

7 Abdul Latif, Hukum Administrasi..., op.cit., P. $165 \& 166$. 
consistency of the law, so that such law can be a guarantee for the achievement of substantial justice, "... where wi find formal justice, the rule of law and the honoring of ligitimate expectations, we are likely to find substantive justice as well".8

In practice, the current fair legal process, we also understand that what is stated by Rawls is, of course, open to further thought, because the formal performance of the law is not free from manipulation originating from non-legal sectors, for example the political sector and the economic sector which became the basic motivation for Kelsen to develop teachings about pure law. ${ }^{9}$

In contrast to formal legal certainty obtained mainly through consistent performance, material legal certainty will be read in a proportionate sense of justice that emerges when behaviors that deviate from legal norms obtain judgments with varying weights.

Of course, we cannot say that there is a formal legal certainty, if last year the act of corruption was subjected to criminal penalties, while a month ago it was treated as an act subjected to civil sanctions, or maybe even just an administrative act which of course would not have made

society the more law-abiding or more disciplined. Nor can we say that there is a certainty in a material law, if a treasurer of an office of a village head or a school principal corrupts "village level", and a state official who corrupts at the level of "state institutions" with a loss of state money in the amount much larger, eventually subject to the same prison fund, for example four years. The existing criminal law philosophically prioritizes legal certainty over justice. ${ }^{10}$

Criminal law is currently felt to be lacking in fulfilling justice and peace in social life, because the many criminal acts that have occurred lately make the law no longer a social control but the number of certain people using the law as a mouthpiece for committing crimes, this is due to the lack of effect deterrent caused by the criminal law itself. ${ }^{11}$

Consistency in criminal law enforcement and justice is not something that happens automatically, so there can be a risk that the implementation of law enforcement becomes inconsistent. It can even be said that inconsistent law enforcement and justice must

10 Sri Endah Wahyuningsih, 2018, Model Pengembangan Asas Hukum Pidana Dalam KUHP Berbasis Nilai-Nilai Ketuhanan Yang Maha Esa, Fastindo, Semarang, P. 2.

11 Safaruddin Harefa, Penegakan Hukum Terhadap Tindak Pidana Di Indonesia Melaui Hukum Pidana Positif Dan Hukum Pidana Islam, UBELAJ, Volume 4 Number 1, April 2019, P.35-57 
remain consistent in that inconsistency. Even though this is actually absurd, the connotation is that everyone can understand the inconsistent conditions of the law and community institutions, so that everyone may be indirectly encouraged not to expect too much from law enforcement and defend themselves, that is the reality is happening today.

Related to theoretical discussions about the criminal justice system, it is always reminded of the principle of "presumption of innocence", which must be a "common thread" that knits throughout this fair legal process. What is meant by "guilty" here is in a legal sense (by a court decision) and not "wrong as a fact" (crazy people who kill guilty according to facts, but not guilty according to law). In this regard, we are always reminded that although we can always maintain and discipline ourselves not to violate criminal law, but we cannot guarantee ourselves to be free from the risk of being suspected according to the conviction of law enforcement solely.

Criminal law is felt to be more effective and reliable in order to regulate and bring order to the people through legislation. Most legislative products always include chapters on criminal sanctions or chapters on criminal provisions, this indicates the instrument of criminal law is an effective instrument in, law enforcement of the laws made. ${ }^{12}$

he risk of being a suspect of a criminal offense is always there and threatening a community member and cannot be avoided, as is the possibility of having a traffic accident outside of our faults. For this reason, in a country that upholds the rule of law in which no citizen can be immune (nobody is impune), we are required to support and fight for the strict enforcement of a fair legal process in the criminal justice system. ${ }^{13}$

That the "due process of law", derived from the Magna Charta 1215 document, is a "constitutional guarantee ... that no person will be deprived of life, liberty or property for reasons that are arbitrary". This legal process "... protects the citizen against arbitrary actions of the government". Therefore the essence of a fair legal process is as follows:

a. The suspect (as well as the defendant) has the right to be heard in his views on how the alleged incident happened (hearing);

\section{Kukuh Subyakto, Azas Ultimum Remedium Ataukah Azas Primum Remedium Yang Dianut Dalam Penegakan Hukum Pidana Pada Tindak Pidana Lingkungan Hidup Pada UU Nomor 32 TAHUN 2009 Tentang Perlindungan dan Pengelolaan Lingkungan Hidup, Jurnal Pembaharuan Hukum, Volume II No. 2 Mei - Agustus 2015, P.209-213}

13 Abdul Latif, Hukum Administrasi..., op.cit., hlm. 167. 
b. During hearings (from the first time in the police) he is always entitled to be accompanied by a legal counsel;

c. The Defendant has the right to the broadest opportunity to arrange and submit his defense (defense);

d. It is the duty of the public prosecutor to prove the accused's guilt with legal evidence (legal evidence);

e. The court that checks it must be free from pressure from anyone and with a judge who is not fair (a fair and imparfial coun).

Investigation and prosecution based on law, as well as criminal punishment by the court are considered as matters that do not need to be considered as legal matters anymore. People easily demand that a person who is considered an "enemy" immediately changes his legal status to a "suspect" who needs to be punished immediately. It is not uncommon that this kind of process, which is often followed by the degradation of individual citizens who have been named suspects and defendants, is of the opinion that legal defense and legal arguments about facts and mistakes are made up. We have seen this kind of process at the beginning and during the New Order era and there is a tendency to occur again during this reform era.

What must be prevented is that in an atmosphere where we will re-establish the rule of law, there will be an injustice process through a people's court (mobjustice lynchjustice) which tarnishes the ideals of reform in the field of law. This tendency must be anticipated and neutralized by those working in the criminal justice system, namely judges, prosecutors, defenders and the police. The quality and integrity of law enforcers and the court must be able to restore the people's trust in the true rule of law. However, this system built by humans, will also be easily damaged by humans, as has been seen so far. One effort to reduce this possibility is to uphold legal principles in a fair process of law context.

\section{Legal Aspects in the realization of Justice}

The ideals or ideology of the criminal justice system in a civilized country are included in the sentence "fair legal process". Opponents of this process are "arbitrary processes". This arbitrary process is carried out solely based on the authority of law enforcement. This authority is even greater if the judge can be influenced by the government bureaucracy, because there will be arbitrary where the criminal justice process is a "farce" to carry out injustice.

Law enforcers who are directly involved in the law enforcement process have a very important role in the 
success of criminal law enforcement in the community. Law enforcement can be done if the law enforcers are a professional, mentally tough and have moral integrity, high ethics.

According to Lawrence M. Friedman, there are 3 elements of the operation of law as a system that (1) structural, (2) substantive and (3) legal culture. The three elements cannot be separated from one another. Structural Elements according to Lawrence M. Friedman states that the structure of a system is its skeletal frame work, it is the permanent shape, the institutional body of the system. The structure of a system is the framework design, a permanent form, the institutional body of a system. Lawrence M. Friedman said, substance is composed substantive rules and rules about how institutions should behave. The substance of legislation such as the Criminal Procedure Code is how these institutions must operate in criminal proceedings that have been arranged so well, and this is the legal basis for processing a criminal case. ${ }^{14}$

The sources of formal law do not always run as originally intended. The values in the legal norms must be confronted with the values and

14 Ediwarman, Paradoks Penegakan Hukum Pidana Dalam Perspektif Kriminologi Di Indonesia, Jurnal Kriminologi Indonesia Vol. 8 No.1 Mei 2012, P.38-51 value systems that exist in individuals and communities that are subjected to the validity of these legal norms. The results of interactions that come from individuals / communities and values derived from legal norms are living laws. These are called living law.

Mistakenly the meaning of "fair legal process", by law enforcers (police, prosecutors and judges), is often interpreted to mean only the literal application of applicable criminal law. Though the meaning that should be used is as an inner attitude of respect for the rights of citizens, even though he is a criminal.

If the application of the law is carried out by judges with a legalistic outlook, the resulting justice will be rigid. But if the judge is not legalistic, then he will interpret the law with a progressive view, then the justice he produces is also progressive. So according to Harifin, justice resulting from a process will depend on how the judge interprets and applies existing law, both formal and material law. ${ }^{15}$

Hans Kelsen abstracts them as two meanings of a feeling of justice, namely:

a. As an inner attitude that requires fair treatment and does not require unfair treatment;

b. An inner attitude that is free from positive law that 
receives fair treatment or rejects unfair treatment.

However, one thing should be noted that the sense of justice is relatively difficult to be applied and applied in general, because everyone has a subjective feeling that distinguishes fair actions from unjust ones. In the case, in human relations an objective order is generally accepted so that the sense of personal justice does not break as a discrepancy in the sense of justice between individuals, or worse, a cross in a sense of justice between individuals. Because of that, at the very least an agreement is needed regarding the signs of justice, so that traffic between the sense of justice does not collide with each other.

Based on that consensus, citizens of the same community can agree to apply the principle of equal treatment to everyone involved in the same case or case by applying the same norms. This principle is similar to the principle that applies to judges.

Therefore, there must be law as a basis for decision intended to prevent judges or other officials from acting arbitrarily, namely to decide according to their own will which in turn will cause injustice and legal uncertainty that is contrary to a fair legal process. The foundation of law enforcement that can respond to the demands of society must be responsive law, otherwise the law will lose its spirit. Moral and justice are the spirit of law. Legal reform must look back at the record of morality that lives, grows and develops in society. The voices of the people from below must arrive at the time to be respected, by formulating various policies as outlined in the products of legal development.

According to Paton, the essence of legal development is legal development and legal reform. Legal development is the treatment of existing laws, not destroying them but letting them grow, while legal reform is forming new legal orders. ${ }^{16}$

Law enforcement is an effort to realize the ideas and legal concepts that people expect to become reality. Law enforcement is a process that involves many things. As for Philipus Hadjon, the important elements of the Indonesian law state based on Pancasila are as follows:

a. Harmony of relations between the government and the people based on harmony;

b. A proportional functional relationship between state powers;

c. The principle of deliberation and dispute resolution is a last resort if the deliberation fails;

d. Balance between rights and obligations.

16 Sri Endah Wahyuningsih, 2013, Perbandingan Hukum Pidana, Dari Perspektif Religipus Law System, Cetakan Kedua, Unissula Press, Semarang, P. 4. 
Based on these elements, efforts to protect the law for the community should be directed at: ${ }^{17}$

a. Efforts to prevent disputes or reduce disputes so that preventive means of legal protection need to be prioritized more than repressive legal protection;

b. Efforts to settle disputes between the government and the people by means of a full family consultation;

c. Settlement of disputes through the judiciary is a last resort and not a forum of confrontation so that in the judiciary a peaceful and peaceful atmosphere is reflected through the law of the event.

The purpose of the law based on the ideals of the law is to provide protection to humans, namely to protect people passively by preventing arbitrary and active actions by creating humane social conditions that allow the social process to take place naturally so that every human being has the broadest and equal opportunity to develops its full potential for humanity.

\section{CONSLUSION}

The implementation of justice in criminal law enforcement in
Indonesia can be said to be far from the goal that Indonesia wants to realize as a state of law. There are still cases where the handling is not in accordance with the law because of abuse of authority by law enforcers, as well as decisions that are not in accordance with material justice. Enforcement of law and justice in the context of a fair legal process is a guarantee of the rule of law in realizing a sense of justice and felt for the justice seeker community as a reality, that law enforcers who use their power arbitrarily are contrary to the due process of law and the principle of presumption of innocence, there is law enforcement that is contrary to the human rights of citizens. 


\section{BIBILIOGRAPHY}

\section{Books:}

Abdul Latif, 2014, Hukum Administrasi Dalam Praktik Tindak Pidana Korupsi, Cetakan Kesatu, Kencana Prenada Media Group, Jakarta;

Achmad Sulchan, Rekonstruksi Penegakan Hukum Terhadap Perkara Pidana Pemilihan Umum Berbasis Nilai Keadilan, Jurnal Pembaharuan Hukum Volume I No. 3 September - Desember 2014;

Daniel S. Lev, Hukum dan Politik di Indonesia, Kesinambungan dan Perubahan., LP3ES, Jakarta;

Ediwarman, Paradoks Penegakan Hukum Pidana Dalam Perspektif Kriminologi Di Indonesia, Jurnal Kriminologi Indonesia Vol. 8 No.1 Mei 2012;

Harifin A. Tumpa, 2011, Transparansi Merupakan Pintu Keadilan Dan Kebenaran, Pidato Pemberian Penghargaan Doktor Honoris Causa Dari Universitas Hasanuddin Makassar;

Kukuh Subyakto, Azas Ultimum Remedium Ataukah Azas Primum Remedium Yang Dianut Dalam Penegakan Hukum Pidana Pada Tindak Pidana Lingkungan Hidup Pada UU NOMOR 32 TAHUN 2009 Tentang Perlindungan dan Pengelolaan Lingkungan Hidup, Jurnal Pembaharuan Hukum, Volume II No. 2 Mei - Agustus 2015;

Safaruddin Harefa, Penegakan Hukum Terhadap Tindak Pidana Di Indonesia Melaui Hukum Pidana Positif Dan Hukum Pidana Islam, UBELAJ, Volume 4 Number 1, April 2019;

Sri Endah Wahyuningsih, 2013, Perbandingan Hukum Pidana, Dari Perspektif Religipus Law System, Cetakan Kedua, Unissula Press, Semarang;

Sri Endah Wahyuningsih, Rismanto, Kebijakan Penegakan Hukum Pidana Terhadap Penanggulangan Money Laundering Dalam Rangka Pembaharuan Hukum Pidana Di Indonesia, Jurnal Pembaharuan Hukum, Volume II No. 1 Januari - April 2015;

Sri Endah Wahyuningsih, 2018, Model Pengembangan Asas Hukum Pidana Dalam KUHP Berbasis Nilai-Nilai Ketuhanan Yang Maha Esa, Fastindo, Semarang; 